\title{
BETWEEN THE VALLEY AND THE HILL TOP. DISCOURSING ON THE SPATIAL IMPORTANCE OF PEGO'S BRONZE AGE NECROPOLIS, BRAGA (NORTHWEST OF PORTUGAL)
}

\author{
HUGO ALUAI SAMPAIO ${ }^{(1)} \&$ ANA M.S. BETTENCOURT ${ }^{(2)}$
}

\begin{abstract}
:
This work reports the data which has been recovered from the excavation of Sector II of Pego. Among other kinds of evidence, that area encompasses traces of funerary practices dating back to the Bronze Age.

Based upon the local's choice, the structures' architectonic features, their interrelations, materials associated and stratigraphy and in the carbon dating results available we have proposed different uses and occupation phases.

Although certain materials reflect human presence during later periods, the frequency of that area denounce three occupation moments datable from between the Middle Bronze Age and the Late Bronze Age. These moments are consistent with the construction of a plain grave's necropolis, probably forming familiar clusters, a hypothetic pits' necropolis and, prior to the abandonment of the area, an "enclosure".

Given the interpretations presented we have discussed the possible relation between the local, certain physical characteristics and the presence of funerary practices. As a work hypothesis we consider those relations as fundamental for the places' choice. Alongside with other evidence of difficult interpretation and, perhaps, in the context of new senses meanwhile acquired by this place, these data form part of this place's biography.
\end{abstract}

Keywords: Portuguese Northwest, Bronze Age, necropolis, flat graves, pits, ceramic depositions, deathscape.

Resumo:

\begin{abstract}
Entre o vale e o monte. Refletindo sobre a importância espacial da necrópole da Idade do Bronze do Pego, Braga (Noroeste de Portugal)

O presente trabalho apresenta os dados de escavação relativos ao Sector II do Pego, área onde foram identificadas, entre outras, evidências de práticas funerárias da Idade do Bronze.

Com base na escolha do local, nas caraterísticas arquitetónicas das estruturas, nas suas inter-relações, nos materiais a elas associados, na sua estratigrafia e nas datas de radiocarbono disponíveis são propostos diferentes usos e fases de ocupação.

Embora certas materialidades denunciem presença humana posterior, a frequência da área denuncia quatro momentos de ocupação datáveis entre o Bronze Médio e o Bronze Final. Esses momentos são compatíveis com a construção de uma necrópole de sepulturas planas, quiçá formando núcleos familiares, com uma hipotética necrópole de fossas e, antes do abandono do local, com um "recinto".

Atendendo ao quadro interpretativo apresentado, discute-se a possível relação entre o local, certas caraterísticas do meio e os vestígios das ações funerárias. Como hipótese de trabalho consideram-se tais relacõoes como fundamentais para a escolha deste lugar. A par de outros vestígios de interpretação mais difícil e, talvez, no quadro de novos sentidos entre-
\end{abstract}

Keywords: Early and Middle Bronze Age; Burial architectures, Construction materials, Reuse, Burial pratices.

Received: 25 November 2013; Accepted: 10 January, 2014

"How things are materialized depends upon the language, the concepts, the experiences, and the power relations which converge
on a particular experience. So just as we cannot look back at the ancient past and imagine that those people understood their own
bodies in the same way as we do in the present, we equally cannot imagine that the significance of material culture is fixed and
changeless".

Julian Thomas (2005: 17)

"Any form of life is created by a dialogical encounter between past and present, as past meanings derived from past experience are tested against the exigencies of the present".

Christopher Gosden (1994: 52)

\section{INTRODUCTION}

The discovery of Pego in 2003 lead to archaeological excavations resulting from different contexts. After a first evaluation carried out by archaeological surveys, assigned by Acheo'Estudos. Investigação Arqueológica, $L d a$., the archaeological works proceeded under the project The Entre-o-Douro landscape between the III and the I millenniums $B C^{l}$. These works were coordinated by one of the authors (A.M.S.B.) until 2007.

(1) Doutorando em Arqueologia na Universidade do Minho. Investigador do Centro de Investigação Transdisciplinar Cultura, Espaço e Memória - CITCEM/ UM. Campus de Gualtar, 4710-059, Braga, Portugal. E-mail: hugoaluai@gmail.com

(3) Departamento de História da Universidade do Minho, Campus de Gualtar, 4710-059, Braga, Portugal. Investigadora do Centro de Investigação Transdisciplinar Cultura, Espaço e Memória - CITCEM/UM. E-mail: anabett@uaum.uminho.pt

Projeto financiado pela Fundação para a Ciência e Tecnologia (ref. POCTI/HAR/36527/2000). 
The subsequent works continued under the doctoral thesis project submitted by one of the signers $^{2}$ (H.A.S.), entitled Bronze Age places in the river Ave's basin. More recently, this work integrated the interdisciplinary project named Natural Spaces, Architectures, Rock Carvings and Depositions of the Western Façade of the Central-Northern Portugal Late Prehistory: from Agencies to Meanings ${ }^{3}$, equally lead by one of the authors (A.M.S.B.).

From these different works resulted two publications (SAMPAIO et al. 2008; SAMPAIO \& BETTENCOURT 2011) and the preparation of a monograph chapter is to be included in the aforementioned doctoral thesis.

The campaigns developed between 2003 and 2010 enabled the recovery of an important set of information significantly relevant for the Bronze Age understanding. Although some evidence identified in other areas of the site denounce different activities, some of which datable from historic phases, this work will only focus in the so-called Sector II. In that area, corresponding to the South slope of a knoll and alongside with Bronze Age mortuary practices, other activities have occurred, which its interpretation is complex. Altogether its analysis may contribute to a better knowledge of the Northwestern Iberian Bronze Age funerary contexts and practices.

\section{LOCATION AND PHYSICAL CONTEXT}

The site of Pego is located in Souto, parish of Cunha, county and district of Braga, in the North of Portugal. According to the World Geodetic System 1984 (WGS84) is positioned at the geographic coordinates of 41, $4939 \mathrm{~N}$ and -8, $5206 \mathrm{~W}$ (Fig. 1).

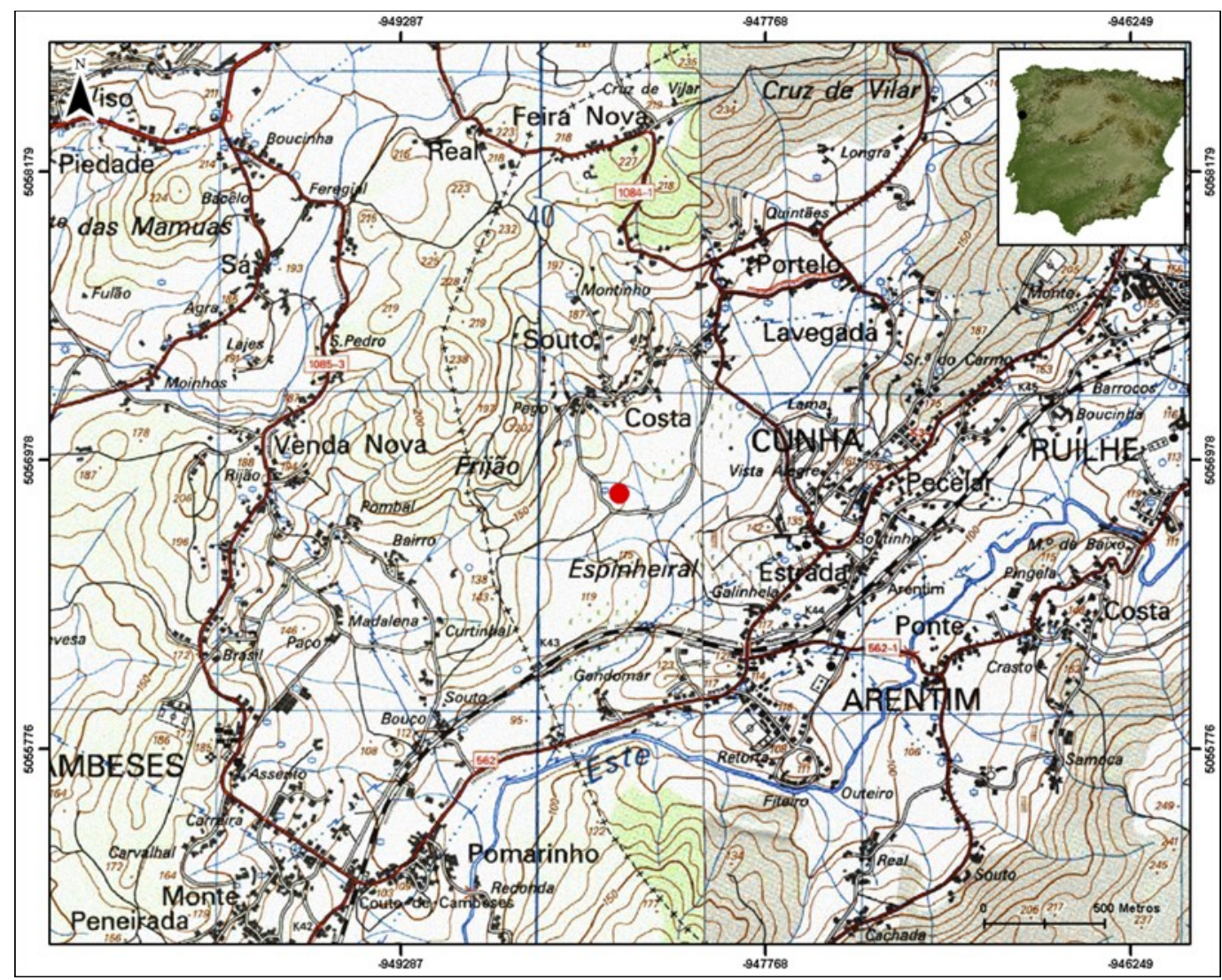

Fig. 1. Portuguese Military Chart excerpt, sheet 69 , at scale 1/25 000, reproducing 3D terrain modeling with Pego's location (red dot).

Fig. 1. Localização do Pego (círculo vermelho) em excerto de Carta Militar de Portugal, $\mathrm{n}^{\circ}$ 69, à escala $1 / 25$ 000, reproduzindo o modelo 3D do terreno.

Ph.D. scholarship granted by Fundação para a Ciência e Tecnologia (ref. SFRH/BD/41776/2007) with Plano Nacional de Trabalhos Arqueológicos aproved by the extinct IGESPAR, IP [ref. 2008/1(554)].

Ref. PTDC/HISARQ/112983/2009. 
It occupies a little knoll with 150 meters of maximum altitude that corresponds to a flattened spur. This knoll integrates a wider mount that from Sequeira grows in that direction, reaching the $220 / 240$ meters of altitude.

The knoll is flanked from East by the Levegada's stream. Its valley is mainly developed from Northeast to Southwest, coursing between moderate granitic reliefs lower than 270 meters of altitude, and joining the river Este at about $1 \mathrm{~km}$ to South. As so, Pego integrates the river Ave's basin (Fig. 2). Not far to the Southwest it was possible to identify a paleochannel, cut in the edge of a nearby pathway owned by a local home-keeper. It is likely that this paleochannel might have been active during the Bronze Age. Within 50 meters to the North there is known to be a potable water source.

This positioning allows for excellent visibility conditions, in particular between the Northeast and the South. Concretely, to the wider alluvial valley of Levegada's stream, with sprawled banks on which proliferate suitable agricultural soils.

The local rock substratum is mainly constituted by biotitic monzogranites, with rare muscovite, porphyroids, of coarse grains, often outcropping (TEIXEIRA \& MEDEIROS 1969). The regional climatic conditions impel the bedrock meteorization, in many cases promoting its arenization (GONÇALVES 2013).

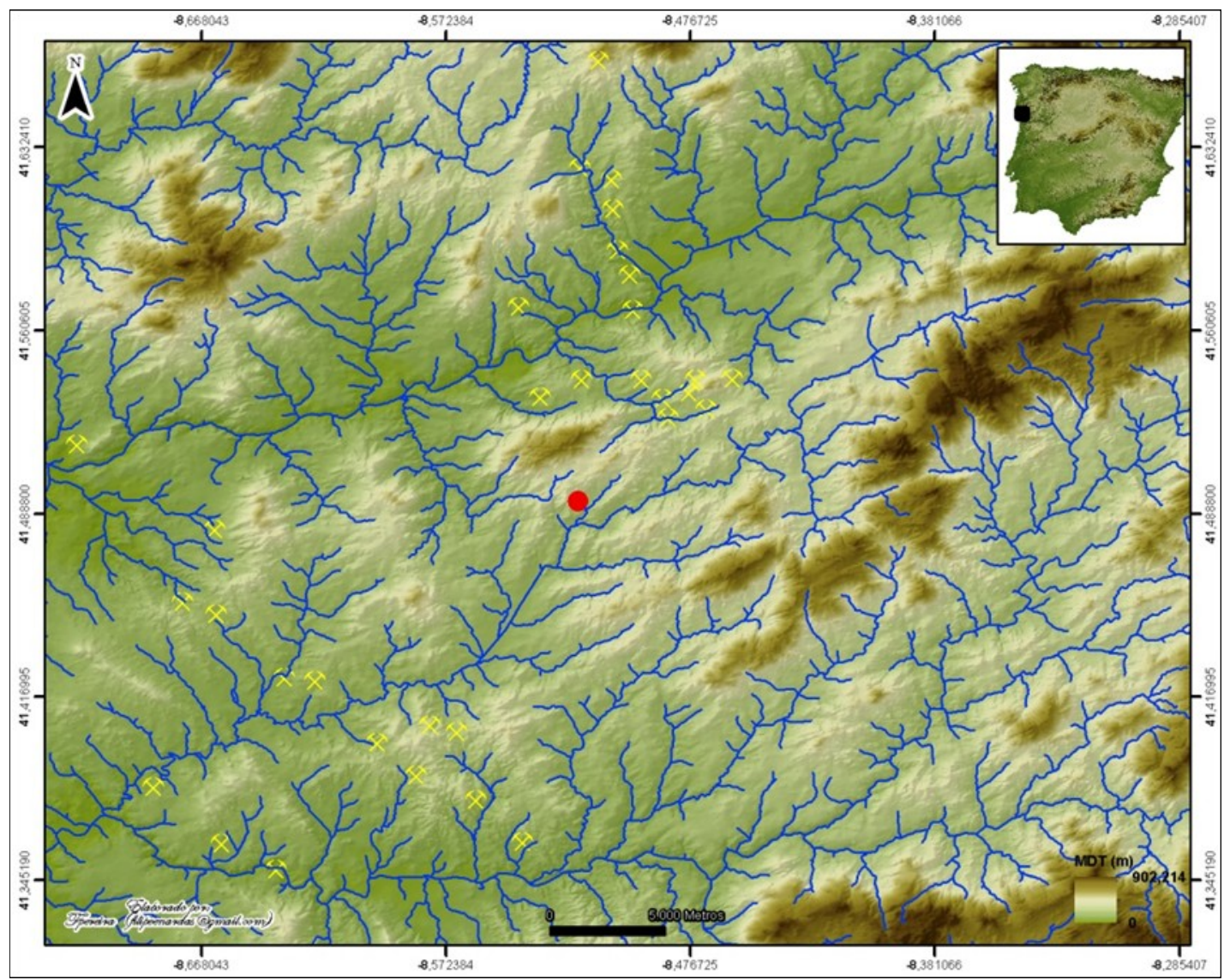

Fig. 2. Hypsometric map with Pego's location towards the nearby hydrological and tin (at yellow) sources.

Fig. 2. Mapa hipsométrico com a localização do Pego em relação aos recursos hidrológicos e mineiros (a amarelo) imediatos.

Analysing the Portuguese Geological Charts, sheets 5-C from Barcelos (TEIXEIRA \& MEDEIROS 1969), 5-D from Braga (FERREIRA et al. 2000), 9A from Póvoa de Varzim (TeIXEIRA \& MEDEIROS 1965) and 9-B from Guimarães (ANDRADE \& NORONHA 1986), at the scale of $1 / 50.000$, it is possible to identify several ore resources in a radius inferior to $25 \mathrm{~km}$ : at a maximum of $13 \mathrm{~km}$ to the Northeast - the tin-mining complex of Negreiros (Barcelos) / Lousado (Vila Nova de Famalicão); at about $8 \mathrm{~km}$ to the Southwest - the tin-mining resources spread between Cabreiros and Padim da Graça (Braga); at about $19 \mathrm{~km}$ to the South - the tin mines of Parada de Gatim / Cabanelas (Vila Verde); and at about $25 \mathrm{~km}$ to the South - the gold minerals of Portela das Cabras (Vila Verde) (Fig. 2). The proximity of the rivers Cávado, Ave and Este, waterways of considerable dynamic available at about $10 \mathrm{~km}$, also facilitated the gathering of alluvial native minerals like gold, silver and tin (Fig. 2).

Although tendentiously sparse, the current 
land cover is formed by arboreal, shrubby and herbaceous species, and the nearest terrains located on lower altitudes, close to the river Este's valley, as already said, are suitable for agriculture.

A dozen meters to the Southwest are known the archaeological sites of Frijão I and Frijão II, dating back to Bronze and Iron Age, respectively (BARBOSA \& AZEVEDO 20042005).

\section{METHODOLOGICAL APPROACH}

Theoretically the dynamic concept of landscape is assumed according to Ingold (2000), perceived as the dialectic result between the human agency and the physical scenario where man lives. The landscape is also the perception and the experience that communities obtain and create from the surrounding world. As so, it is a complex and a permanently (re)constructed element which actuates many times as an agent.

Inherent to its existence in the world, man embodies and recreates different places. These known, experienced and practiced places promote the sense of belonging and social integration, culminating in the attainment of a sense of place (FELD \& BASSO 1996; VAN DYKe \& AlCOCK 2003). Their frequency and use is connected with actions, histories, memories, feelings and meanings, allowing for populations to develop an emotional relation to different places.

The experienced loci become significant, incorporating individual and collective memories. Sometimes, its uses, frequencies and alterations left "readable" archaeological traces. Therefore, the recurrent use of particular places enables the construction of memoryscapes, where people, agencies and memories converge (CLACK 2011). The specific case of Pego takes the form of deathscape (COOK 2011: 14), a place where the performance of "mechanisms in the construction and negotiation of identity, heritage and attitudes towards death" led to the creation of a place for death. Like Thomas (2001: 175) wrote, landscape allows for the permanent remembrance of the relation between the living and the deceased generations and consequently between lines of affiliation and succession.

Based on these assumptions this work prioritized both micro and intrasite scales of analysis. Firstly, we observed independently the structures' features, focusing their constructive elements. Their shape, depth, spatial orientation, stratigraphy and covering was carefully analyzed and compared.

The performed rites were another contemplated item. The absence of osteological remains, due to the Portuguese Northwestern soils' typical acidness, forced us to pursue new work methods in order to minimize the lack of information. The excavation in plan (and not sectioned) of the structures' stratigraphy allowed, in some cases, the identification of organic matter's concentration distributed in the central area of some structures. This concentration of organic matter was linked to the corpses' decay inside the grave.

We also focused on the materials deposited inside those structures, whose origin we related directly to the funerary practices which occurred in this space. In this sense, the analytical observation of the ceramic vessels recovered inside each grave took into account some technical, morphological and stylistic aspects, so as their positioning inside all structures.

Seeking to clarify the internal organization of that area and to assess the necropolis' spatial and social organization, we have considered the interrelations between structures, between groups of structures and between ceramic depositions.

Simultaneously, we prioritize the necropolis' chronological dating and the identification of different occupation moments. These moments, datable back to the Bronze Age, were also object of scrutiny, in order to identify any traces of continuity or disruption amidst them. This was supported by radiometric dating that ground the proposed chronology.

We also took into account the necropolis' positioning in relation to the knoll and to some natural elements, such as watercourses and solar cycles.

Finally, and based on the Peninsular Northwestern Bronze Age occupation, we attempted some parallels with other known coetaneous places.

\section{DATA}

The earliest occupation of Sector II is related with the construction of 13 plain graves. The layouts of those structures reveal a common orientation, aligning their longer axis from the Northeast towards the Southwest.

Their shapes are predominantly subrectangular, only oval in graves 4 and 10. All the sections are in " $U$ " and their bases are flattened, except in graves 8, 9, 10 and 11, which are rounded.

They exhibit variable measures of length, height and depth, ranging between 130-245 cm, 40-90 $\mathrm{cm}$ and 12-40 cm, respectively (Tab. 1).

The absence of osteological remains disabled the identification of their heads. However, we identified inside the fillings of graves 9 and 11, during the excavation in plan and in central positioning, different layers that suggest them. This may be inferred by a dark coloration, which we relate with the presence of 
Table 1. Shape, section, base, dimensions (in $\mathrm{cm}$ ) and longer axis orientation from Pego's plain graves Tabela 1. Forma, secção, base, dimensões $(\mathrm{em} \mathrm{cm})$ e orientação do maior eixo das sepulturas planas do Pego

\begin{tabular}{|c|c|c|c|c|c|c|c|}
\hline Structure & Shape & Section & Base & $\begin{array}{c}\text { Lenght } \\
(\mathbf{c m})\end{array}$ & $\begin{array}{c}\text { Width } \\
(\mathbf{c m})\end{array}$ & $\begin{array}{c}\text { Depth } \\
(\mathbf{c m})\end{array}$ & Orientation \\
\hline Grave 1 & Subrectangular & $\mathrm{U}$ & Flattened & 206 & 62 & $20 / 32$ & NE/SW \\
\hline Grave 2 & Subrectangular & $\mathrm{U}$ & Flattened & 212 & $40 / 86$ & $14 / 30$ & $\mathrm{NE} / \mathrm{SW}$ \\
\hline Grave 3 & Subrectangular & $\mathrm{U}$ & Flattened & 245 & 56 & $21 / 30$ & $\mathrm{NE} / \mathrm{SW}$ \\
\hline Grave 4 & Ovoid & $\mathrm{U}$ & Flattened & 130 & 60 & 16 & $\mathrm{NE} / \mathrm{SW}$ \\
\hline Grave 5 & Subrectangular & $\mathrm{U}$ & Flattened & 120 & 46 & $13 / 22$ & $\mathrm{NE} / \mathrm{SW}$ \\
\hline Grave 6 & Subrectangular & $\mathrm{U}$ & Flattened & 180 & 80 & $10 / 32$ & $\mathrm{NE} / \mathrm{SW}$ \\
\hline Grave 7 & Subrectangular & $\mathrm{U}$ & Flattened & 224 & 72 & $12 / 20$ & $\mathrm{NE} / \mathrm{SW}$ \\
\hline Grave 8 & Subrectangular & $\mathrm{U}$ & Rounded & 202 & 62 & $28 / 34$ & $\mathrm{NE} / \mathrm{SW}$ \\
\hline Grave 9 & Subrectangular & $\mathrm{U}$ & Rounded & 215 & 80 & 30 & $\mathrm{NE} / \mathrm{SW}$ \\
\hline Grave 10 & Subrectangular & $\mathrm{U}$ & Rounded & 210 & 70 & 40 & $\mathrm{NE} / \mathrm{SW}$ \\
\hline Grave 11 & Subrectangular & $\mathrm{U}$ & Rounded & 200 & 70 & 36 & $\mathrm{NE} / \mathrm{SW}$ \\
\hline Grave 12 & Subrectangular & $\mathrm{U}$ & Flattened & 30 & 90 & 24 & $\mathrm{NE} / \mathrm{SW}$ \\
\hline Grave 13 & I.N.A. & I.N.A. & I.N.A. & I.N.A. & I.N.A. & I.N.A. & $\mathrm{NE} / \mathrm{SW}$ \\
\hline
\end{tabular}

I. N.A. - Information not available.

organic matter and resulting from the corpses' decaying (Fig. 4).

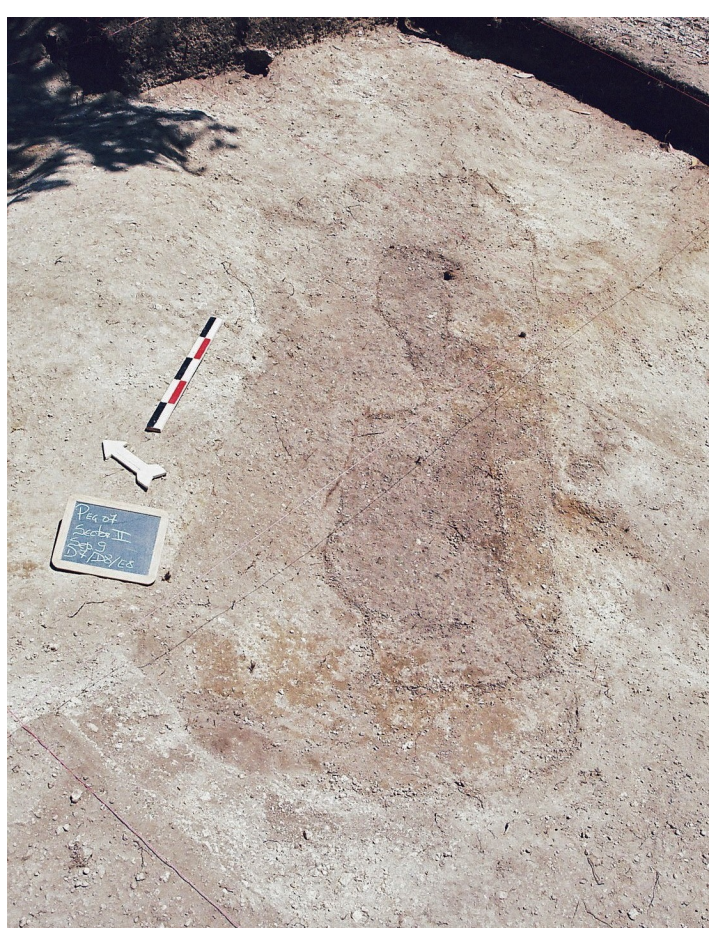

Fig. 4. Grave 9 and its darkest filling in the centre, resulting from body's decomposition.

Fig. 4. Sepultura 9 e enchimento mais escuro no centro, resultante da decomposição do corpo.
The top of graves $3,8,9,10$ and 11 was sealed with a layer of gravel (Fig.5). Unfortunately, the level of destruction of the remaining graves precluded the observation of the same type of cover. At the top of the Southwest edge of grave 11 was found an angular granitic pebble nailed into the soil, making its interpretation difficult.

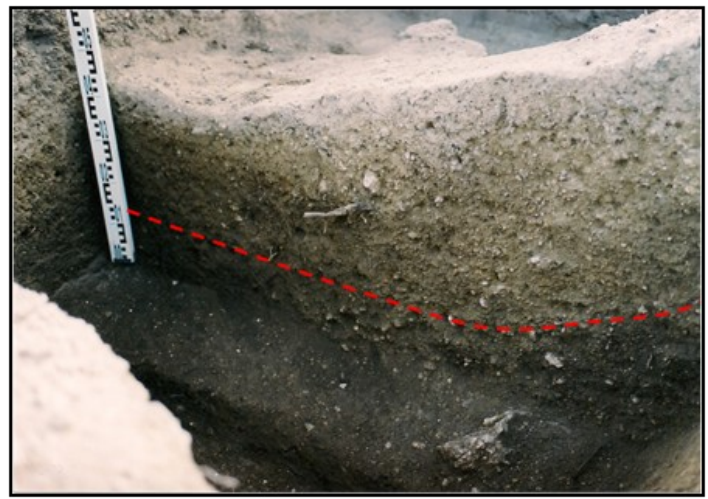

Fig. 5. The red dashed line defines the gravel layer identified on top of grave 6 that served as cover.

Fig. 5. A linha a tracejado de cor vermelha define a camada de saibro identificada no topo da sepultura 6 , que serviu como tampa.

Except for graves 1, 4 and 7, all the others included the deposition of a ceramic vessel (Fig 6). In graves 7 and 8 was also recovered a loom weight or net weight and a spindle whorl or bead (Fig. 7). 


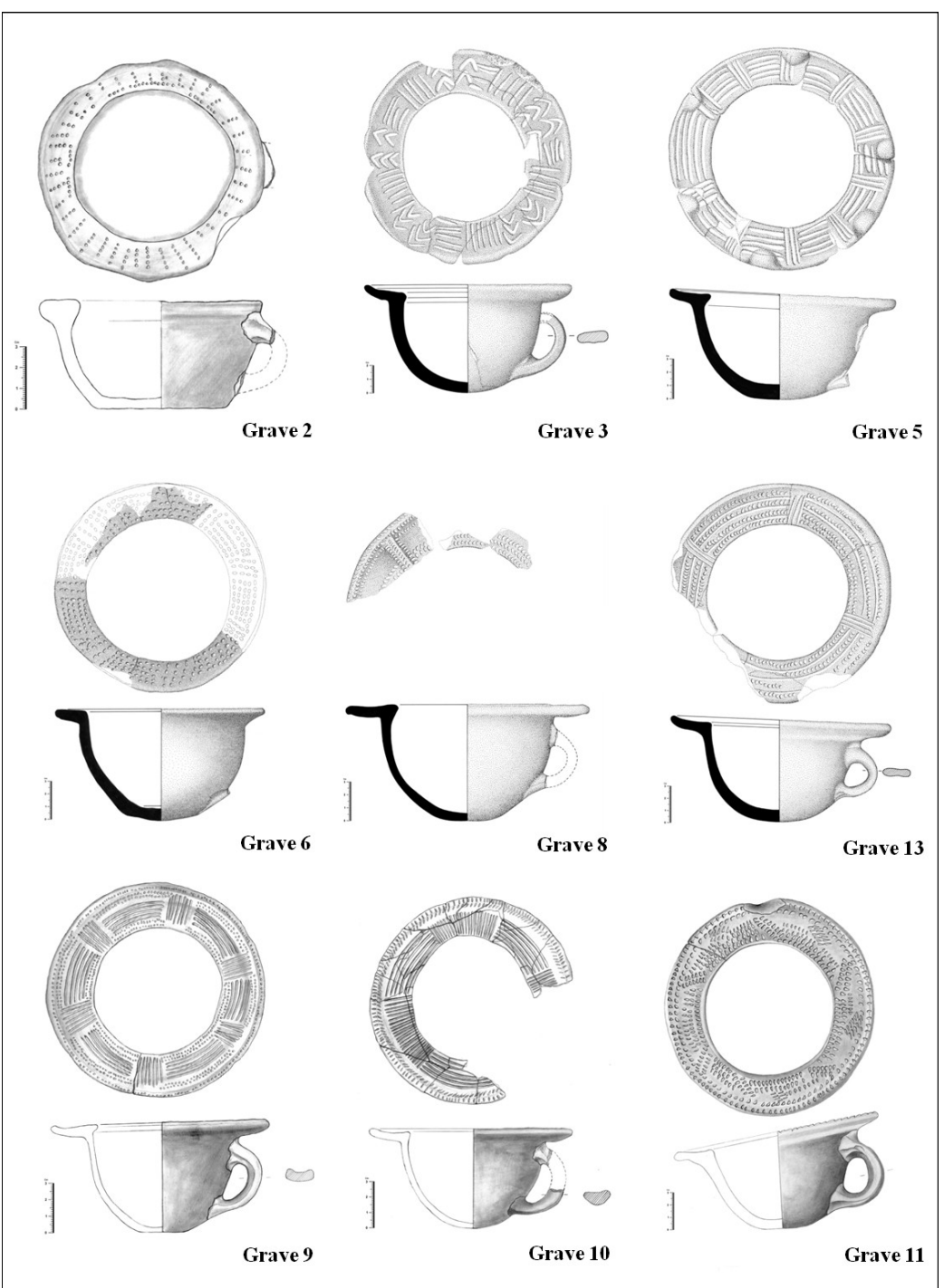

Fig. 6. Ceramic vessels recovered from the fillings of the plain graves identified in Pego's Sector II

Fig. 6. Vasos cerâmicos recolhidos do enchimento das sepulturas planas identificadas no Sector II do Pego

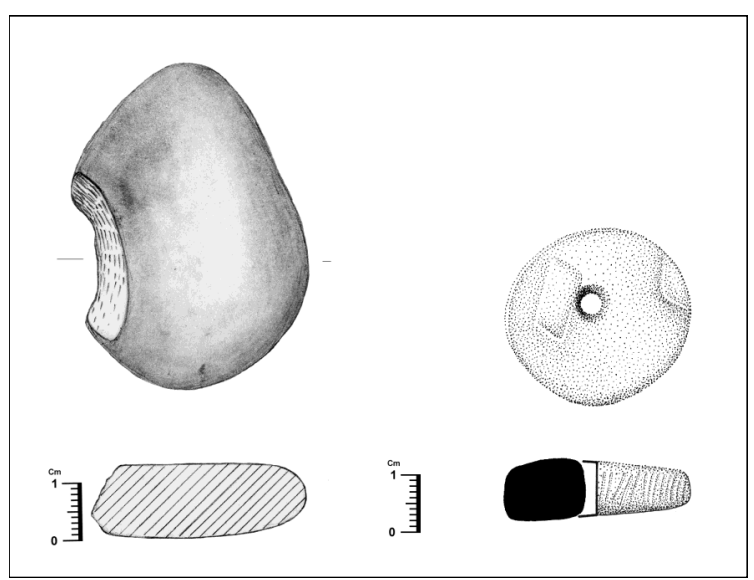

Fig. 7. Spindle whorl or bead and loom weight or net weight, recovered from plain graves 8 and 7 , respectively

Fig. 7. Cossoiro ou conta de colar e peso de tear ou de rede recolhidos, respetivamente, das sepulturas 8 e 7 
Observing the spatial distribution of the graves one can verify the formation of two clusters, which may be compared with the segmented model described by M.P. Pearson (1999). These were named of nucleus 1 and nucleus 2 (Fig. 8).
Nucleus 1 occupied the upper area of the South slope of the knoll and includes graves $7,8,9,10,11,12$ and 13 (Fig. 7A). The maximum lateral length between graves 7,8 and 11 reaches approximately $120 \mathrm{~cm}$. Among graves 9, 10 and 12 the length is

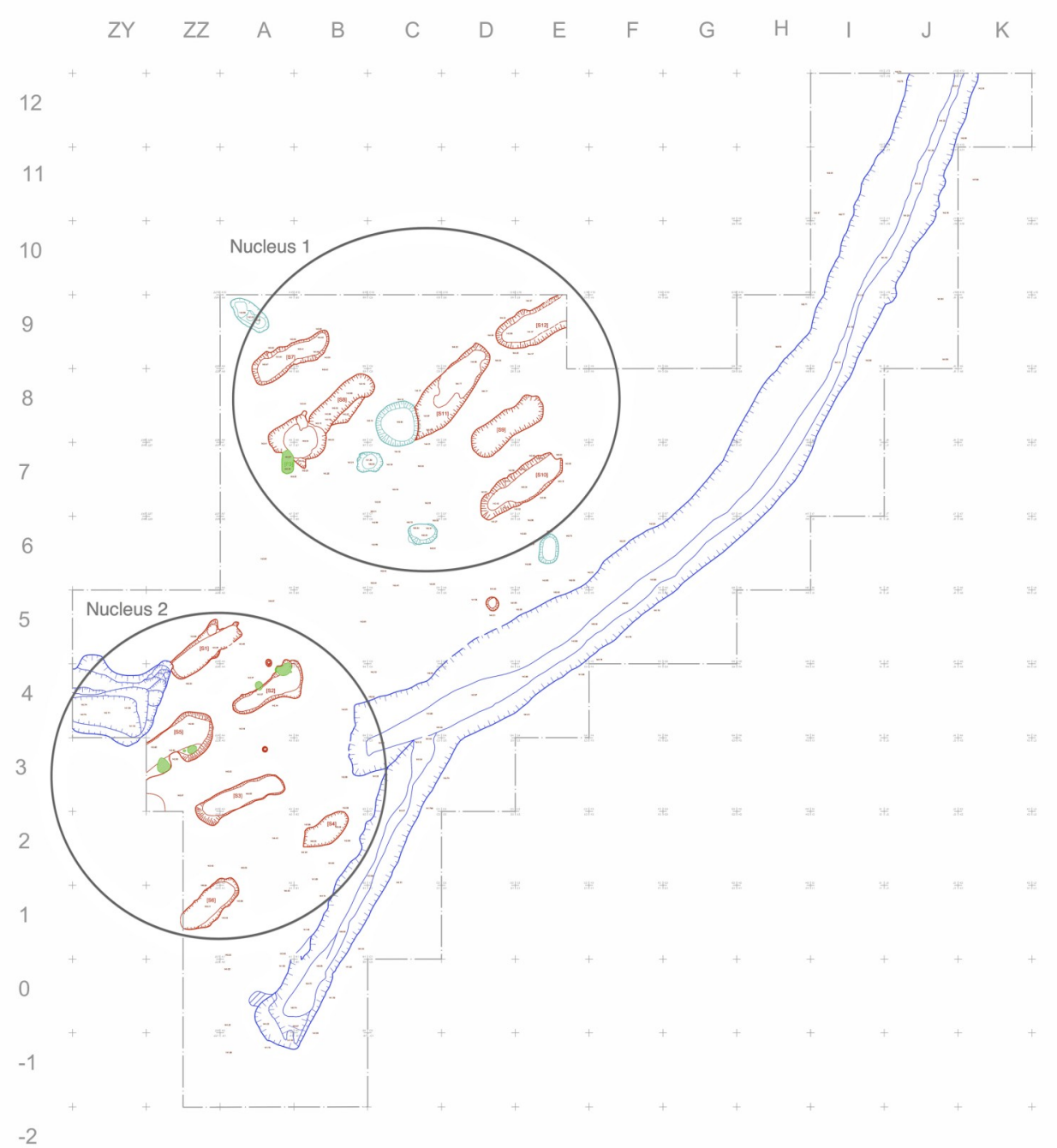

$-2$

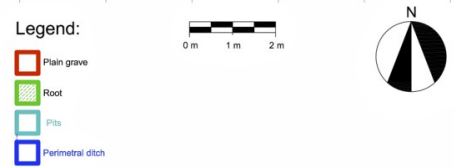

Fig. 8. Spatial distribution of the plain graves from nucleus 1 and nucleus 2 . In light blue one can see the pits, from a later date, and in green the disturbances of the roots.

Fig. 8. Distribuição espacial das sepulturas planas do núcleo 1 e do núcleo 2. A azul claro é possível observar as fossas, de cronologia posterior, e a verde, perturbações de raízes. 
about $70 \mathrm{~cm}$. Amidst opposite ends of different graves we can only register $40 \mathrm{~cm}$ between graves 11 and 12. Except for graves 7 and $12^{4}$, all the others included ceramic vessels with flat edges (form 13 from BETTENCOURT 1999). These vessels were all recovered at the Southwest end of the graves ${ }^{5}$ (Fig. 6).

The positioning of their handles inside different structures was variable, whereby no regularity was identified. Only the vessel of grave 9 held external wall burnished and internal wall smoothed, while the others have smoother finishing both on internal and external walls. Technical features and decorative compositions analysis allowed some inferences. However, for the prior reported reasons, grave 12 was not contemplated. All the decorations were distributed in metopes and demonstrate significant complexity. The most frequent decoration techniques conjugate the of use impression and incision, although in the vessel from grave 8 impression and plastic addition techniques were simultaneously used, the later in the form of slightly prominent stands transversal to the lip. Likewise, only in the vessel of grave 11 the use of impression is present. Indeed, this was taken as the "simplest" composition. Graves 7 and 8 also stand out, since their fillings included the deposition of a loom weight or net weight and a spindle whorl or bead (Fig. 7).

Nucleus 2 occupied the Southwest area, slightly below nucleus 1 , and included graves 1 ,
2, 3, 4, 5 and 6 (Fig. 8). The lateral height between graves 3 and 6 reached about $140 \mathrm{~cm}$ and among graves 1, 2, 3, 4 and 5 about $120 \mathrm{~cm}$. Between the opposite ends of graves 2 and 5 the maximum height was registered, $70 \mathrm{~cm}$. Except for graves 1 and 4 all the others contained a ceramic vessel inside their fillings. In graves 3 and 6 these were deposited in the Southwest quadrant, whilst in graves 2 and 5 in their Northeast end (Fig. 6). The position of the handles was variable, and no regularity was observed. The internal and external walls of all the vessels denounce a smoothed finishing. Like nucleus 1 , the decorative compositions also denote the use of metopes, in some cases evidencing significant complexity, prevailing the conjugation of incision and impression techniques. Whereby, only the vessel from grave 5 denoted simultaneously the application of incision and plastic addition, the later taking the form of slightly prominent protuberances. Likewise, only the vase from grave 2 denoted the use of impression, exhibiting the "simplest" decorative composition.

Other signs of occupation are materialized by the presence of 6 pits dug on the rocky substratum. These were located very close to plain graves, in some cases even overlapping them (Fig. 8). The majority held an oval shape, with length, widths and depth ranging between 60-78 $\mathrm{cm}, 32-52 \mathrm{~cm}$ and 30-68 $\mathrm{cm}$, respectively (Tab. 2).

Table 2. Shape, section, base, dimensions (in $\mathrm{cm}$ ) and longer axis orientation of the pits from Sector II Tabela 2. Forma, secção, base, dimensões $(\mathrm{em} \mathrm{cm})$ e orientação do maior eixo das fossas do Sector II

\begin{tabular}{|c|c|c|c|c|c|c|c|}
\hline Structure & Shape & Section & Base & Lenght & Width & Depth & Orientation \\
\hline Pit 1 & Ovoid & $\mathrm{U}$ & Leveled & 68 & 52 & $36 / 40$ & E/W \\
\hline Pit 2 & Ovoid & $\mathrm{U}$ & Leveled & 78 & 52 & $36 / 68$ & E-W \\
\hline Pit 3 & Ovoid & $\mathrm{U}$ & Irregular & 64 & 32 & $39 / 45$ & N-S \\
\hline Pit 4 & Ovoid & $\mathrm{U}$ & Irregular & 120 & 56 & $24 / 48$ & NW-SE \\
\hline Pit 5 & Subcircular & $\mathrm{U}$ & Rounded & 124 & 118 & 32 & - \\
\hline Pit 6 & Ovoid & $\mathrm{U}$ & Irregular & 60 & 52 & $30 / 52$ & N-S \\
\hline
\end{tabular}

\footnotetext{
Nevertheless, we must underline that the excavation of grave 12 was not completed. From its fillings we recovered three pot sherds apparently belonging to another flat edge vessel. Numerous eucalyptus roots are responsible for the disturbance of this structure, especially its Northeast quadrant. This occurrence does not invalidate the possibility of another deposition of a vessel inside this structure.

In grave 8 it was not possible to recover the vessel in its original position, since a massive root disturbed its Southwest quadrant. The vessel was recovered in dispersed sherds, which permit to consider its original deposition in that area of the grave.
} 
Pit 4 may correspond to a first pit later cut by another similar structure, as apparently prevail its original interface in the Southeast quadrant. It held $120 \mathrm{~cm}$ in length, $56 \mathrm{~cm}$ in weight and 24 to $48 \mathrm{~cm}$ of depth. Pit 5 , substantially different from the others, had a circular shape with $124 \mathrm{~cm}$ of diameter and reached a maximum depth of $32 \mathrm{~cm}$. Its most particularity was to overlap grave 11, cutting its Southwest end. Beside no evidence of debris in their fillings, the top of pits 1,2 and 5 were sealed with a gravel layer (Fig. 9), whereas pits 1,2 and 4 were marked with an angular granitic pebble at their top.

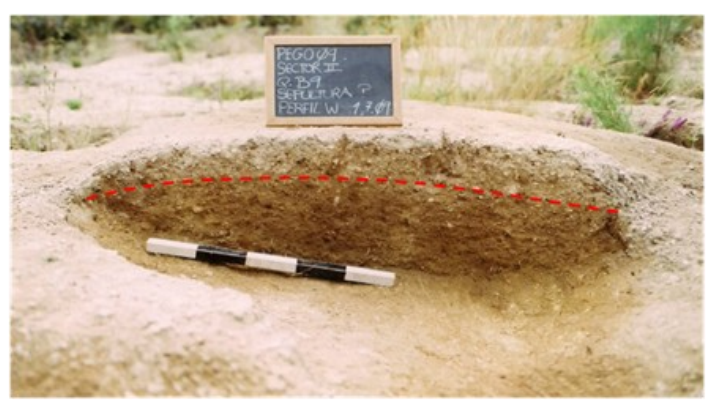

Fig. 9. The red dashed line defines the gravel layer identified on top of pit 5 .

Fig. 9. A linha a tracejado de cor vermelha define a camada de saibro identificada no topo da fossa 5 .
Pit 1 included roughly in its middle a subcircular four stones arrangement, three of which were non local granites with high percentage of biotite. This feature conferred to those stones a black glassed appearance. Hypothetically, this arrangement could have served as base to host something, like a body, bones or any other perishable offerings.

In general the materials recovered inside their fillings did not abound: from pit 1 only a pot sherd belonging to a belly was recovered; in pit 2 a piece of yellow dye was identified; and from pit 3 some pot sherds that allowed the partial reconstruction of a little pot's profile were exhumed.

\section{5. $C^{14}$ DATES AND OCCUPATION PHASES}

It was an option to date scraped residues of soot identified in the internal wall of the vessel deposited in grave 9 . The carbon dating results situated the plain graves of this context between the XVIII and $\mathrm{XV}$ centuries $\mathrm{BC}$, that is, in the second quarter of the I millennium BC and in what is generically accepted as regional Middle Bronze Age (Tab. 3).

Such chronology is compatible with other flat edge vessels recovered elsewhere in the river Ave's basin, like Quinta do Amorim 2 (SAMPAIO et al. 2014), for example. Therefore, the previous proposed chronology for that area of Pego is receded, since it was prior ascribed to Late Bronze Age (SAMPAiO et al. 2008; BETTENCOURT 2010).

Table 3. AMS date from the grave 9

Tabela 3. Datação por AMS da sepultura 9

\begin{tabular}{|c|c|c|c|c|c|c|}
\hline Lab. Ref. & Context & Sample & Age BP & $\begin{array}{c}\text { 1 Sigma Cal. BC } \\
\mathbf{( 6 8 . 2 \% )} \text { Método B }\end{array}$ & $\begin{array}{c}\text { 2 Sigma Cal. BC } \\
\mathbf{( 9 5 . 4 \% )} \text { Método B }\end{array}$ & Bibliography \\
\hline \multirow{2}{*}{ AA89666 } & Grave 9 & Soot & $3328 \pm 51$ & $\begin{array}{c}1680-1674(2.8 \%) \\
1669-1601(34.8 \%) \\
1592-1532(30.6 \%)\end{array}$ & $1740-1499(95.4 \%)$ & Unpublished \\
& & & & & \\
\hline
\end{tabular}

The structures' spatial distribution and interrelation analysis allows for the understanding of its chronological sequence. Therefore, the plain grave 11 was cut by pit 5 , corroborating the older construction of the later structure. The cut of the Southwest end of grave 1 happened in a later phase, during the construction of the perimeter ditch. And pit 6 was covered with gravel that also resulted from the opening on the rock substratum of that perimeter ditch.

Therefore, based on the stratigraphic record, the interrelation between structures, in the recovered materials and in the available carbon dating results we have proposed four different occupation moments for the South slope of Pego's site.

The first moment dates back, at least, to the Middle Bronze Age, specifically, to the second quarter of the II millennium BC (XVIII-XV centuries $\mathrm{BC}$ ). This occupation phase corresponds to the construction of a plain grave's necropolis. A latter moment is related with a hypothetical pit's necropolis that was constructed in the immediate area of the plain graves. Although there are no carbon dating results available that securely confirm their chronology, based on the interrelations between structures listed above one can situate them between the second and the fourth quarter of the II millennium $\mathrm{BC}$, that is, between the XVIII-XV centuries BC (date from the plain grave's necropolis) and XII-X centuries BC (date from the perimeter ditch's opening). Subsequent moments date back to Late Bronze Age, more precisely, from between the XII-X centuries BC and IX-V centuries BC (SAMPAIO et al. 2008). These moments 
were matched to the opening and closure of the perimeter ditch that surrounded the knoll.

\section{FROM THE CONSTRUCTION OF A PLAIN GRAVE'S NECROPOLIS TO ITS TRANSFOR- MATION IN AN ENCLOSURE}

The absence of osteological remains requires some explanation that support the interpretation of certain structures as plain graves and the South slope of Pego (Sector II) as a necropolis. These assumptions were based upon the shapes, the contours, the dimensions, the stratigraphy and the materials deposited inside those fillings' structures.

It was referred that during the excavation in plan of graves 9 and 11 were individualized dark layers. Their central distribution was related with the decomposition of the deceased. As such, it is feasible to hypothesize that each of these graves hosted a primary inhumation.

The compact gravel layer identified on top of graves $3,8,9,10$ and 11 suggests their sealing with this kind of material.

Other coetaneous contexts like Pego, where similar plain graves were identified, are known in the Northwestern Iberian Peninsula: Tapado da Caldeira, in Baião (JORGE 1980a, 1980b, 1983, 1985); Cimalha, in Felgueiras (ALMEIDA \& FERNANDES 2007, 2008; ALMEIDA et al. 2008); Alto da Vela/Gulpilhares, in Vila Nova de Gaia (FORTES 1909); Quinta do Amorim 2, in Braga (SAMPAIO et al. 2013); Coto da Laborada, Calvos de Randín (LóPez CueviLlas 1930, 1947; LÓPEZ Cuevillas \& LORENZO FERnÁNDEZ 1930); or Monte de Mesiego, O Carballiño (LOPEZ CUEVILLAS \& LAMAS 1958).

The presence of flat edged ceramic vessels inside the great majority of these graves enhances the sepulchral nature of this context. In Northwestern Iberia there other necropolis where these kind of ceramic forms were exhumed: Belinho, in Esposende (AlmEIDA 1986); Monte da Ola, in Viana do Castelo (PAÇO 1933; DINIS \& BETTENCOURT 2004); Faísca, in Guimarães (CARDOSO 1936); Cimalha, in Felgueiras (ALMEIDA \& FERNANDES 2007, 2008; ALMEIDA et al. 2008); Alto da Vela/Gulpilhares, in Vila Nova de Gaia (FORTES 1909); or Coto da Laborada, in Calvos de Randín (LÓPEZ CueviLlas 1930). We can also highlight the necropolis of Agra de Antas, in Esposende, where osteological remains were recovered (ATAÍDE \& TEIXEIRA 1940; CRUZ \& GONÇALVES 1998/1999; BETTENCOURT 1999; CUNHA \& BETTENCOURT 2013).

Attending to the general similitude observed between graves it is feasible to assert that during the Middle Bronze Age a plain grave necropolis at Pego's Southern slope was built. This necropolis hosted primary inhumations deposited in lateral decubitus - at least in two cases, graves 9 and $11-$, sealed with gravel layers and containing, in most cases, ceramic offerings and, more rarely, other objects.

The angular pebble identified at the Southwest top of grave 11, interpreted as a marking element, lead us to hypothesize that some of these structures may have been marked with perishable materials and/or additional structures.

Their organization in clusters enables us to question if their disposition can represent familiar groups. The answer is not easy but the analysis of the decorative techniques and compositions of the ceramic vessels appear to show that in each nucleus prevails heterogeneity on the decorative techniques and patterns. This may indicate distinct elements of a family, according to a subdivision respecting the age, gender or other attributes/ predicates. We also denote that there are recurrences in each nucleus, related with vessels' positioning and certain decorations. That is, each nucleus includes a vessel decorated with plastic addition; one vessel decorated only by impression of diagonal metopes and graves with absence of vessels occupied identical intra-nucleus positions. It seems reasonable to interpret either nucleus as a different familiar group, albeit deriving from the same community, with specific norms/standards towards death. The humble dimensions of this place and the lack of superimpositions between structures may corroborate the construction and frequency of this necropolis by one single community.

The location of this necropolis, between the top of the hill and the valley, in the South slope of a little knoll, its closeness to a nearby watercourse flowing from the North/Northeast to the South/ Southwest, and its viewing of the Levegada's stream were some of the physical features considered important. According to Tim Ingold's landscape concept (INGOLD 2000) these may not be random items. On the contrary, probably these were foundational factors taken into account during the choice of this locus for its use to perform sepulchral practices. As such, these factors were agents riddled with cultural and symbolic significances.

The preferential area chosen for the construction of the necropolis was the sunny quadrant of the knoll, facing the South. Can the manorial characteristics of this area, well illuminated from sun rise to sunset, reveal any association between the solar cycles and death and life cycles? We do not know, but this work hypothesis can be raised, albeit more data is needed to corroborate its veracity. Could the similarity between Levegada's stream and the graves' orientations (Northeast-Southwest) indicate any association between the flow of the waters and the journey to death? We also do not know.

Besides, the necropolis occupied the soft 
slope of the knoll, in the area with the best access to the nearest fertile valleys. It is located between the valley and the hill top, in a liminal position, that is, a passage area between low and higher lands. Can this physical characteristic be associated with death, also seen as a passage between two worlds? It seems likely since it is a recurrent location observed in other necropolis that we are studying.

It is curious to register that at the top of the knoll no necropolis' coetaneous occupation was identified. This may lead us to consider the South slope of Pego as a deathscape in the sense of Clack (2011), that is, an area where actions and memories towards death took place. Only this way Pego could be articulated with other nearest significant and experienced places from the Middle Bronze Age landscape. Probably recurrently used as a necropolis, this place subsisted in the everyday life, at least, for some time. We do not know if its memory remained active and if Pego became a memoryscape, that is, a place of people's, agencies' and memories' convergence in its large duration. The various occupations identified dating back from between the II and the I millenniums BC, as we shall see, prove that Pego was occupied several times.

The presence of pits in the plain graves necropolis' area is enigmatic. No specific spatial disposition stands out, but its proximity to one cluster (nucleus 1) is clear. Although the absence of osteological remains incites to careful interpretations, funerary pits' contexts in the Northwestern Iberia are known. We may refer, for example, Fraga do Zorro, in Verín (FÁBREGAS VALCARCE 2001; PRIETO MARTínEZ et al. 2009), or Medal, in Mougadouro, this last site recently discovered and presented $^{6}$.

The sealing of pits 1,2 and 5 with gravel and the marking of pits 1,2 and 4 with an angular pebble resemble some plain graves characteristics, and may denounce analogous purposes. We also need to refer to their non detrital fillings and distinct forms, when compared with storage pits defined by Buxó (1997), whose sections are funnel-shaped. As so, their ceremonial or commemorative role can be questionable. Denouncing evident links with funerary practices, by their proximity to some plain graves (nucleus 1), it is possible that they served as containers to hold depositions or offerings in perishable materials. Such a situation is compatible, for example, with the subcircular base formed by four rocks which was identified thereabout the middle interior of pit 1 . This stony arrangement may have received a child's body, an ossuary, a reduction, etc.

Finally, both South slope and the knoll were circumscribed by a perimeter ditch. Its stratigraphy confirms a simultaneous construction throughout the different areas of the knoll, which carbon dating results situate on the regional Late Bronze Age. This circumscription may be interpreted as the construction of an "enclosure" that, at a certain time, was circled by a palisade (SAMPAIO et al. 2008). However, its purposes seem to move away from the original funerary features attached to the site. This may be explained by the alteration and/or renovation of the significances and senses attributed by the communities to this place, during its long diachrony.

Like other topics, the study of the Bronze Age funerary ambiences reflects the complexity of the communities that once practiced them. Just as today, their dealing towards the inevitability of death assumed unique perceptions and understandings about the phenomenon. As such, each funerary context revealed - more or less singular - may open a new window to our interpretation about the past and how populations coped and acted with the loss of their loved ones. At the same time, it increases our interpretative possibilities on the living ones, in other words, on the lifestyles of the populations that erected those sites for the dead and participated in the funerary ceremonies.

\section{AKNOLdGMENTS}

To Foundation for Science and Technology, by the Ph.D. grant conceded (reference SFRH / BD / 4177 / 2007), to the directive and technical team of D. Diogo de Sousa Archaeological Museum, in Braga, specially all the support provided by Clara Lobo, Manuel Santos and Amélia Marques, and to Filipe Pereira and Hélia Aluai Sampaio, for the elaboration, respectively, of the maps and drawings.

This work was accomplished in the scope of Bronze Age's Places in the Ave's basin [LIBVA - P.N.T.A. $2008 / 1$ (554)] and Natural Spaces, Architectures, Rock Carvings and Depositions of the Western Facade of the CentralNorthern Portugal Late Prehistory : from Agencies to Meanings - ENARDAS (reference PTDC/HIS-ARQ/112983/2009), funded by Operational Programme Thematic Factors of Competitiveness - COMPETE and cofinanced by the European Community Fund - FEDER.

\section{BIBLIOGRAPHY}

ALMEIDA, C.A.B. 1986. Carta arqueológica do concelho de Esposende. Boletim Cultural de Esposende, 9/10: 39-59.

AlmeIdA, P.B. \& FERNANDES, F. 2007. A escavação arqueológica no povoado das Cimalhas - Felgueiras. Oppidum, 2: 115-123.

AlmeidA, P. B.\& FERNANDES, F. 2008. O povoado da Idade do Bronze da Cimalha. Oppidum, Número Especial: 2944.

\footnotetext{
"Ocupação da Idade do Bronze no Terraço da Foz do Medal (vale do Sabor)", presented by R. Gaspar, J. Carrondo, L. Nobre, Z. Rodrigues and G. Donoso in the $5^{\text {th }}$ Conference of Quaternary, University of Oporto, December $13^{\text {th }}$ and $14^{\text {th }}$ of 2013 . The carbon dating announced situates this context between the XVIII and XVII centuries BC (1768-1606 Cal. BP).
} 
Almeida, C.A.B.; AlmeidA, P.B. \& Fernandes, F. 2008 Povoado do Bronze Final da Cimalha: relatório da interpretação arqueológica. Felgueiras: Câmara Municipal.

Alonso Matthias, F. \& Bello DiÉguez, J.M. 1997. Cronología y periodización del fenómeno megalítico en Galicia a la luz de las dataciones por C-14. In A. Rodriguez Casal (ed.) O Neolítico Atlántico e as Orixes do Megalitismo. Actas do Coloquio Internacional (Santiago de Compostela, 1996). Santiago de Compostela, 507-520.

Andrade, M.; Noronha, F. \& RochA, A. 1986. Carta Geológica de Portugal na escala 1:50 000. Notícia explicativa da folha 9B (Guimarães). Lisboa: Serviços Geológicos de Portugal.

AtAíDE, A. \& TeIXEIRA, C. 1940. A necrópole e o esqueleto de S. Paio de Antas e o problema dos vasos de largo borde horizontal. Actas do $1{ }^{\circ}$ Congresso do Mundo Português (Lisboa, 1940). Lisboa, 669-692.

BARbosA, R. \& AzeVEDo, M. 2004-2005. A antropização da paisagem no vale do Este: dados inéditos para o seu estudo. Minia, 11-12 (3ª série): 113 -136.

Bettencourt, A.M.S. 1999. A Paisagem e o Homem na bacia do Cávado durante o II e o I milénios AC (5 Vols.). Braga: Universidade do Minho (Tese de doutoramento - policopiada).

Bettencourt, A.M.S. 2010. La Edad del Bronce en el Noroeste de la Península Ibérica: un análisis a partir de las prácticas funerárias. Trabajos de Prehistoria, 67 (1): 139-173.

BuXó, R. 1997. Arqueología de las plantas. Barcelona: Crítica.

CARDoso, M. 1936. Novas urnas de largo bordo horizontal (um tipo regional de cerâmica primitiva). Trabalhos de Antropologia e Etnologia, 8 (1): 65-87.

Clack, T. 2011. Thinking Through Memoryscapes: Symbolic Environmental Potency on Mount Kilimanjaro, Tanzania. In T. Myllyntaus (ed) Thinking Through the Environment: Green Approaches to Global History. Cambridge: White Horse Press, 115-134.

Classen, C.; Howes, D. \& SynnotT, A. 2003. Aroma. The cultural history of smell. London: Routledge.

CoOK, H.R. 2011. Deathscapes: Memory, Heritage and Place in Cemetery. Ontário: McMaster University (Open Access Dissertations and Theses. Paper 5914).

CruZ, D.J. \& GONÇALves A.A.H.B. 1998/1999. A necrópole de "Agra de Antas" (S. Paio de Antas, Esposende, Braga). Portugalia, 19/20 (Nova Série): 5-27.

Cunha, E. \& Bettencourt, A.M.S. 2013. Bronze Age populations of the Northwest Iberia. Anthropological and pathological features of Quinta de Água Branca (Vila Nova de Cerveira) and Agra de Antas (Esposende), I Bioanthropological Meeting: a Multidisciplinary Approach (Coimbra, 2013). Programa e Resumos. Coimbra: Departamento de Ciências da Vida, Universidade de Coimbra, 63.

Dinis, A \& BetTencourt, A.M.S. 2004. Sondagens Arqueológicas no Monte da Ola, Vila Fria, Viana do Castelo (Norte de Portugal). Portugalia, 25 (Nova série): $75-89$
FÁBREgas VALCARCE, R. 2001. Los petroglifos y su contexto: un ejemplo de la Galicia meridional. Instituto de Estudios Vigueses. Vigo.

Feld, S. \& Basso, K.H. 1996. Senses of PlaCE. SAnTA Fe, New Mexico: SchoOl of American Research Press.

Ferreira, N.; Dias, G.; BragA, M.A.S. 2000. Carta Geológica de Portugal na escala 1:50 0000. Noticia explicativa da folha $5 D$ (Braga). Lisboa: Instituto Geológico e Mineiro.

Fortes, J. 1909. Gaya no passado. Mea villa de Gaya. Porto: Empresa Editorial do Guia Ilustrado de Portugal.

Fox, K. 2010. The Smell Report. An overview of facts and findings. Oxford: Social Issues Research Centre.

GonÇAlves, L. 2013. Estudo Geoarqueológico com Georadar. Aplicação aos contextos arqueológicos da Pré-História Recente à Proto-História do NW de Portugal. Braga: Universidade do Minho (Tese de doutoramento - policopiada).

Gonçalves L., Bettencourt A.M.S. \& Alves M.I.C. 2010. Análises químicas de conteúdos orgânicos de recipientes cerâmicos da Idade do Bronze do Norte de Portugal. III Jornadas do Quaternário - Evolução Paleoambiental e Povoamento no Quaternário do Ocidente Peninsular (Braga, 2010). Programa e Resumos. Braga: APEQ, 8.

Gosden, C. 1994. Social Being and Time: an archaeological perspective. Oxford: Blackwell.

IngOLD, T. 2000. The Perception of the Environment: Essays in Livelihood, Dwelling and Skill. London: Routledge.

Jorge, S.O. 1980a. A necrópole do Tapado da CaldeiraBaião. Arqueologia, 2: 36-44

JoRGE, S.O. 1980b. A estação arqueológica do Tapado da Caldeira, Baião. Portugalia, 1 (Nova série) 29-50.

JORGE, S.O. 1983. Duas datas de $\mathrm{C}^{14}$ para a sepultura 1 da estação do Tapado da Caldeira (Baião). Arqueologia, 8: 55-56.

JORGE, S.O. 1985. Datas de Carbono 14 para a PréHistória Recente do Norte de Portugal: os dados e os problemas. Arqueologia, 12: 154-183.

López Cuevillas, F. 1930. Nuevas cerámicas das antas galegas. Trabalhos da Sociedade Portuguesa de Antropologia e Etnologia, 4: 263-282.

López Cuevillas, F. 1947. Los vasos semiovoides y la cronología de los vasos de ancho borde horizontal. Boletin de la Comisión Provincial de Monumentos Históricos y Artísticos de Orense, 16 (1): $1-12$.

López Cuevillas, F. \& Lorenzo Fernández, X. 1930. Vila de Calvos de Randin. Notas Etnográficas e Folklóricas. Santiago de Compostela: Seminario de Estudios Galegos.

López Cuevillas, F. \& Chamoso Lamas, M. 1958 Una necrópolis de sepulturas planas. Cuadernos de Estudios Gallegos, 13 (39): 273-283. 
PAÇO, A. 1933. Vaso de bordo horizontal, de Vila Fria. Livro de Homenagem a Martins Sarmento. Guimarães: Sociedade Martins Sarmento, 272-276.

PEARSON, M.P. 1999. The Archaeology of death and burial. Texas: A \& M University Press.

Prieto Martínez, M.P.; Lantes Suárez, O. y MartíNEZ CORTIZAS, A. 2009. Dos enterramientos de la Edad del Bronce en la Provincia de Ourense. Actas do $1^{\circ}$ Congresso Transfronteiriço de Arqueologia (Montalegre, 2008). [Revista Aqvae Flaviae 41]: 93-105.

SAmpaio, H.A.; Bettencourt, A.M.S.; Barbosa, R.; DinIS, A. \& CRUZ, D. 2008. A importânica do povoado do Pego no Bronze do Noroeste de Portugal. In E. Ramil Rego (ed.) Actas do 1 Congreso Internacional de Arqueoloxía de Vilalba (Vilalba, 2008) [Férvedes, 5]: 227-233.

SAmpaio, H.A. \& BetTenCourt, A.M.S. 2011. Produção e práticas metalúrgicas da Idade do Bronze no Noroeste português: o caso do Pego, Braga. In C.M.B. Martins, A.M.S. Bettencourt, J.I.F.P. Martins \& J. Carvalho (eds.) Povoamento e exploração dos recursos mineiros na Europa Atlântica Ocidental. Braga: CITCEM e APEQ, 391-407.
SAMPAIO, H.A.; AMORIM, M.J.; VILAS BOAS, L. \& BRAGA, A.C.G. 2014. Contributo para o estudo dos contextos funerários do Noroeste português: o caso de estudo da Quinta do Amorim 2, Braga. Estudos do Quaternário 10: 35-43.

Teixeira, G.; Medeiros, A.; Assunção, C. \& Torre, C.F. 1965. Carta Geológica de Portugal na escala 1:50 000. Notícia explicativa da folha 9-A (Póvoa de Varzim). Lisboa: Serviços Geológicos de Portugal.

Teixeira, C. \& Medeiros, A.C. 1969. Carta Geológica de Portugal na escala 1:50 0000. Notícia explicativa da folha 5C (Barcelos). Lisboa: Serviços Geológicos de Portugal.

THOMAS, J. 2001. Archaeologies of Place and Landscape. In I. Hodder (ed.) Archaeological Theory Today. Cambridge: Wiley, 165-186.

Thomas, J. 2005. Materiality and the Social. In P. Funari, A. Zarankin \& E. Stovel (eds.) Global Archaeological Theory. Contextual Voices and Contemporary Thoughts. New York: Kluwer Academic/Plenum Publishers, 11-18.

VAN DYKe, R.M. \& AlCOCK, S.E. 2003. Archaeologies of Memory: an introduction. In R.M. Van Dyke \& S.E. Alcock (eds.) Archaeologies of Memory. Oxford: Wiley, 1-13. 